\title{
Influence of waterlogging on carbon stock variability at hillslope scale in a beech forest (Fougères forest - West France)
}

\author{
Thomas EGLIN ${ }^{1 *}$, Christian WALTER ${ }^{1}$, Claude Nys ${ }^{2}$, Stéphane Follain $^{1}$, Françoise ForgEARD ${ }^{3}$ \\ Arnaud LEGOUT ${ }^{2}$, Hervé Squividant ${ }^{1}$ \\ ${ }^{1}$ UMR 1069 Sol Agronomie Spatialisation (SAS), INRA, AgroCampus Rennes, France \\ ${ }^{2}$ Unité Biogéochimie des Écosystèmes Forestiers (BEF), INRA, Champenoux, France \\ ${ }^{3}$ UMR Ecobio, Université Rennes I, Rennes, France
}

(Received 23 April 2007; accepted 12 October 2007)

\begin{abstract}
The Kyoto protocol [39] directs the signatory countries including France to establish an inventory of carbon stocks in forests. Precise estimates of carbon stocks are hampered by local spatial variability, in particular in wetland areas [25]. The aims of this work are: (i) to estimate the spatial variability of carbon stocks on two hillslopes presenting respectively, a transition between a well-drained zone and a wetland area over a short-distance, and a very progressive transition; (ii) to correlate this variability with soil waterlogging and topographic variations and (iii) to evaluate carbon stock prediction by modelling waterlogging intensity as soil organic carbon (SOC) stocks increase significantly with waterlogging. However, SOC stocks in redoximorphic soils are highly variable, particularly in zones where carbon is redistributed due to erosion and sedimentation. In the litter and the vegetation, the age and density of the stand are the main explanatory factors of $\mathrm{C}$ variability. Topographic modelling of the waterlogging intensity could improve the spatial estimation of SOC stocks but not of the C stocks in the humus and vegetation.
\end{abstract}

carbon stocks / forest / waterlogging / Fagus sylvatica / soil / hillslope

Résumé - Influence de l'hydromorphie sur la variabilité des stocks de carbone à l'échelle de versants dans une hêtraie (forêt de Fougères Ouest de la France). Influence de l'hydromorphie sur la variabilité des stocks de carbone à l'échelle de versants dans une hêtraie de plaine (forêt de Fougères, Bretagne). Le protocole de Kyoto [39] a amené les pays signataires dont la France à établir un inventaire précis des stocks de carbone dans les forêts. Cependant, la variabilité spatiale observée dans les zones hydromorphes limite la précision de l'évaluation [25]. Les objectifs de ce travail ont été de : (i) décrire la variabilité spatiale des stocks de carbone à l'échelle de deux versants en forêt de Fougères présentant respectivement une transition rapide et une transition progressive entre une zone bien drainée et une zone hydromorphe; (ii) relier cette variabilité à des facteurs explicatifs potentiels (hydromorphie des sols, topographie) et (iii) de déterminer l'apport d'une modélisation topographique de l'hydromorphie sur la prédiction des stocks de carbone. L'effet de l'hydromorphie se traduit par une augmentation significative des stocks de carbone dans les sols. Cependant, les stocks de carbone des sols hydromorphes sont caractérisés par une forte variabilité, en particulier en zones fortement soumises à l'érosion et à la sédimentation. Dans la végétation et les humus, l'âge et la densité du peuplement sont les facteurs influençant le plus la variabilité des stocks. Ainsi, la modélisation topographique de l'intensité de l'hydromorphie permet d'améliorer la précision des estimations des stocks de carbone dans les sols, mais n'a pas d'intérêt pour prédire les stocks des autres compartiments.

stocks de carbone / forêt / hydromorphie / Fagus sylvatica / sol / versant

\section{INTRODUCTION}

Forest biomes represent about $80 \%$ of the total aboveground terrestrial carbon and $40 \%$ of the below-ground carbon [12]. Temperate forests cover about 10 million $\mathrm{km}^{2}(25 \%$ of the world forested area) [18] and are considered to be net carbon sinks with estimates of 1.4 to $2 \mathrm{tC} \mathrm{ha}^{-1} \mathrm{yr}^{-1}[6,30]$. In the mid-1990s, in the European Union (EU) alone, trees accumulated an amount of carbon equivalent to $7 \%$ of the anthropogenic carbon dioxide emissions of the EU $[29,38]$. Thus, temperate forests could play a major role in carbon mitigation. Therefore, the Kyoto protocol [39] directed the signatory countries, including France, to establish a precise inventory of carbon stocks and fluxes in forests.

* Corresponding author: thomas.eglin@u-psud.fr
Carbon is stored in a number of pools in the forest stand (trees, soil, herbaceous layer and dead woody material). The size and the distribution of these pools are heterogeneous and vary depending on the type of forest in relation to climate $[12,17]$, soil management $[17,18]$, frequency of disturbance [17] and level of human-induced degradation [18]. Estimates may be derived using remote-sensing, forest inventories and direct measurements. The accuracy of the method depends on the inventory design, the spatial resolution and precision of the input data. There is no standardized method of extrapolation and evaluation of the precision at a regional scale [22,23].

Carbon stocks in a beech forest (Fougères forest, France) were estimated by using a combination of in-situ field samples with existing soil and vegetation maps [25]. Soil, humus and vegetation stocks were measured at 100 sampling points 

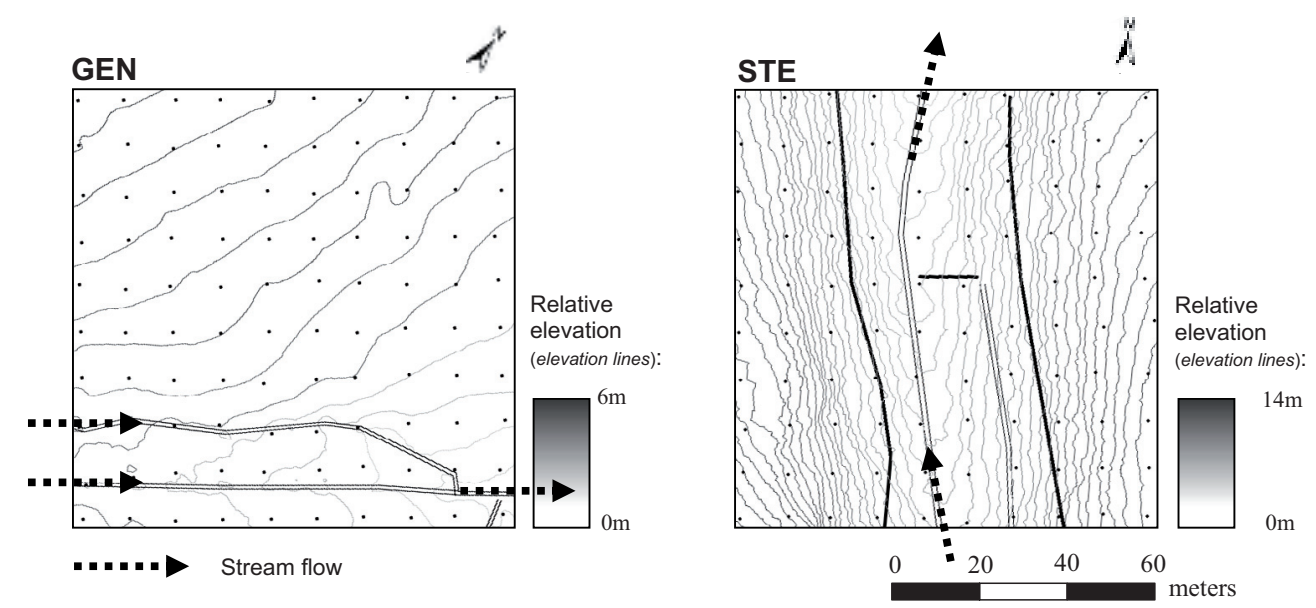

Figure 1. Topography of the two hillslopes (STE and GEN) and location of the sampling points. Elevation lines are represented at $0.5 \mathrm{~m}$ intervals. Embankments are indicated by bold lines and streams by double lines.

distributed throughout representative classes within the whole forest and extrapolated to a forest scale (1600 ha): a strong variability in carbon stocks was observed in the redoximorphic zones especially in soil with an estimated variance 10 times higher than the mean variance of carbon stocks of the forest.

Redoximorphic soils are characterized by specific morphology and function related to waterlogging. They can generally be subdivided into three successive vertical zones with variable thickness: an unsaturated zone, a zone where ground water is present only in a part of the year and processes of reduction and oxidation occur alternately, and a deep zone where waterlogging is permanent and the reduction of iron, manganese and sulphate predominates. Soil carbon stocks are generally considered highest in moist biomes [33]. High soil water content restricts the oxygen supply of micro-organisms, the decomposition rate of dead plant material decreases and more organic matter therefore accumulates. When waterlogging is permanent and close to the surface, the accumulation of organic matter can lead to the formation of thick organic horizons with peaty tendencies $[11,14]$. Soil moisture regime, depletion of dissolved oxygen and substrate instability are also major determinants of plant communities [33]. Numerous authors make use of soil waterlogging criteria to explain plant species distribution $[32,43]$. In relation to climate, soil moisture controls the amount of $\mathrm{C}$ assimilated by vegetation photosynthesis and the $\mathrm{C}$ decomposed in soils and it is therefore a key controller of litter, vegetation and soil C stocks $[19,21]$.

We hypothesized that the spatial variability of carbon stocks observed in redoximorphic soils may be linked to the spatial and temporal variability of waterlogging.

The aims of this work were: (i) to estimate jointly the spatial variability of soil and vegetation carbon stocks on two hillslopes; (ii) to correlate this variability with soil redoximorphism and topographic variations and (iii) to predict carbon stocks by topographic modelling of soil waterlogging intensity.

The components of the ecosystem that were considered were: the vegetation, excluding epiphytes, the litter and the upper $90 \mathrm{~cm}$ of the mineral soil. Due to the low quantity of dead woody material on both sites, this carbon pool was not taken into account.

\section{MATERIALS AND METHODS}

\subsection{Experimental site characteristics}

Fougères state forest is located in the north-east of Brittany (France) $\left(48^{\circ} 23^{\prime} 4^{\prime \prime} \mathrm{N}, 1^{\circ} 8^{\prime} 10^{\prime \prime} \mathrm{W}\right)$. It covers an area of 1600 ha and is dominantly managed as even-aged high beech forest stands [30]. Previous studies have described waterlogged zones in this area as being organized into two systems: a generally well-drained slope and a valley bottom, characterized by waterlogging close to the surface and alternating organic and mineral horizons $[7,10]$.

In this study, two sites were selected to be representatives of two types of transition between a well-drained zone and a waterlogged zone (Fig. 1). A stream runs through both sites. One "steep slope" site (STE) presented two steep slopes $(25 \% \pm 14.9)$ and a fast transition. The limit between slopes and valley were marked on both sides of the stream by two embankments situated about $5 \mathrm{~m}$ from the stream. The other "gentle slope" site (GEN) was characterized by a slight slope $(5 \% \pm 5.3)$ and a very progressive transition.

At both sites, soils had developed in thick aeolian silt overlying a granitic saprolith (Vire granite) [37]. Granitic saprolith was at a depth of 40 to $150 \mathrm{~cm}$. About $23 \%$ of the STE site and $17 \%$ of the GEN site were derived from colluvial and alluvial material. Soils were generally thicker $(>80 \mathrm{~cm})$ and presented a more hydromorphic morphology (e.g. spots of oxidation-reduction, eluvial horizons) in the GEN site than in the STE site. Hydromorphic soils represented $81 \%$ of soils sampled in the GEN site and 38\% in the STE site.

Humus was composed of moders (eumoders and dysmoders) and mulls (oligomulls and dysmulls) [18]. Mulls developed at the bottom of the slope and moders at the top. However, the proportion of mulls was higher in the STE site (61\% of all sampling point) than in the GEN site (21\%) where they were only located along the stream.

Both sites were dominated by beech (Fagus sylvatica L.) (approximately 78\%) and pedunculate oak (Quercus robur L.) (approximately $11 \%$ ). The forest stand was 50 to 60 years old in the STE site with 
1200 stems $\mathrm{ha}^{-1}$, and 120 to 150 years old in the GEN site with 330 stems ha ${ }^{-1}$. In the GEN site, the proportion of beech was lower on the more waterlogged soils with higher proportions of oak (18\%) and hygrophilous trees (4\%): willow (Salix sp.), ash (Fraxinus excelsior L.) and alder (Alnus glutinosa L.).

The understorey vegetation was heterogeneous. Ground ivy ( Hedera helix L.) was present on both sites and was predominant on well-drained slopes. Diversity was higher close to the streams where ferns (Dryopteris filix-mas L., Athyrium filix-femina L., Polypodium vulgare L.), rushes (Juncus sp.), brambles (Rubus rubus L.) and a number of dicotyledonous plants (e.g. Oxalis acetosella L.) were observed. Holly groves (Ilex aquifolium L.) were only present on the GEN site.

\subsection{Sampling design}

At each site, two plots of 1 ha were delimited and surveyed using a $10 \mathrm{~m}$ grid interval referenced to differentially corrected GPS elevations (Trimble Pro XRS, Sunnyvale, CA). The grid interval was chosen to be fine enough to take the high spatial variability of carbon stocks in redoximorphic zones into account. The STE plot included two slopes on both sides of the stream and the GEN plot one slope (Fig. 1). At each grid point, humus and soils were recorded and sampled to a depth of $90 \mathrm{~cm}$. Soil descriptions were carried out on the basis of morphological criteria (colour, oxidation-reduction mottling, coarse elements, texture, and compactness) [1]. Humus was described using the classification defined by Jabiol [20]. In each grid mesh, trees were located by GPS and recorded. Methods of tree inventory, soil and humus description and sampling are described in detail in [25]. Understorey vegetation was divided into three classes: mosses, herbaceous plants and woody plants. The percentage cover was determined in each whole grid mesh and in a $1 \mathrm{~m}^{2}$-quadrat at the centre of the squares. Total understorey vegetation was estimated in the quadrat. Any tree or shrub shorter than $2 \mathrm{~m}$ in height was classified as understorey vegetation.

Topography maps of both sites and their catchment areas (5.7 ha for the STE site and 6.8 ha for the GEN site) were produced using a theodolite (TPS1200, Leica, Germany). Elevation measurement spacing was less than $10 \mathrm{~m}$. 2005.

All of the field sampling was carried out between April and June

\subsection{Carbon stock estimations}

Laboratory analyses and methods of carbon stock estimations are detailed in Lecointe et al. [25]. Soil organic carbon (SOC) stocks down to $90 \mathrm{~cm}$ were determined at 5,10 and $15 \mathrm{~cm}$ increments from the carbon content analysis (NF ISO 10694) and soil bulk density measurements. Bulk density samples were extracted manually by core auger in $754 \mathrm{~cm}^{3}$ steel cylinders. The bulk densities of soil from un-sampled soil depths were estimated by a model adjusted to the Fougères forest soils (RMSE $=0.13 \mathrm{~g} \mathrm{~cm}^{-3}$ ) $[3,26]$. Carbon stocks in humus samples were calculated after oven-drying at $65{ }^{\circ} \mathrm{C}$ and carbon content analysis (CHN:NCS2500, ThermoQuest). Biomass models $[16,41]$ were used to estimate carbon stocks in trees using the species and $\mathrm{C}_{130}$ (circumference at $1.30 \mathrm{~m}$, in $\mathrm{mm}$ ) measurements of each tree. Understorey vegetation samples were oven-dried at $65{ }^{\circ} \mathrm{C}$ and weighed. Mean concentrations of carbon in beech trees in Fougères forest were estimated to be $485 \pm 15 \mathrm{~g} \mathrm{C} \mathrm{kg}^{-1}$ of dry weight [16]. For other species the non-specific value of $500 \mathrm{~g} \mathrm{C} \mathrm{kg}^{-1}$ of dry weight was used [29]. Carbon stocks were expressed in $\mathrm{kg} \mathrm{m}^{-2}$.

\subsection{Spatial Analysis and cartography}

Soil and humus carbon stocks from the sampling points were converted to the plot scale using geostatistical interpolations and an ordinary kriging method [42]. A co-kriging method with topographic data (altitude, slope, curvature) was tested but did not improve the reliability of the interpolation. The resolution of the prediction grid was $1 \mathrm{~m}$. The root mean square errors (RMSE) were estimated by cross-validation from the true data points. For the interpolation of SOC stocks, the RMSEs were $3 \mathrm{~kg} \mathrm{C} \mathrm{m}^{-2}$ and $5 \mathrm{~kg} \mathrm{C} \mathrm{m}^{-2}$ in the STE and GEN sites respectively. For interpolation of humus stocks, the RMSEs were $0.6 \mathrm{~kg} \mathrm{C} \mathrm{m}^{-2}$ and $1.1 \mathrm{~kg} \mathrm{C} \mathrm{m}^{-2}$ in the STE and GEN sites respectively.

Carbon stocks in vegetation were extrapolated at the resolution of the grid mesh $\left(100 \mathrm{~m}^{2}\right)$. Carbon stocks in individual trees were summed and carbon stocks in each of the understorey vegetation classes $(C v$ in $\mathrm{g}$ ) were estimated using the total percentage cover in each $100 \mathrm{~m}^{-2}$ mesh ( $T$ in $\left.\%\right)$, the measured biomass $(B$ in $\mathrm{g})$ and the percentage cover in the $1 \mathrm{~m}^{-2}$ quadrat sampled $(t$ in $\%)$. Biomass was converted into carbon stock using a value of $0.5 \mathrm{~kg} \mathrm{C} \mathrm{kg}^{-1}$ of dry weight for the understorey vegetation biomass. $C v$ was therefore estimated by:

$$
C v=\frac{T}{t} \times 100 \times B \times 0.5
$$

\subsection{Topographic modelling of waterlogging intensity}

Modelling of waterlogging intensity was performed on both sites using a topographic wetness index (TWI) described in the TOPMODEL Beven-Kirkby model [5,8], a rainfall-runoff model which bases its prediction on catchment topography. The wetness index is the log of the ratio of the catchment area and flow-slope. A flat area having a large upslope area will have a relatively high wetness index as compared to steep areas having a relatively small catchment area.

In this study, detailed topography of the sites (1m grid) and a DEM (Digital Elevation Model) of the Fougères region (50 m grid) were used to estimate slopes and the catchment's area for each grid pixel.

\subsection{Statistical Analysis}

The exploratory study was done using the S-Plus 6.2 software package (Insightful Corp, 2003). As the distribution of the C stock data was not normal, we used non-parametric tests (Kruskall-Wallis statistic and Wilcoxon-Mann-Whitney test) [36]. Relationships between $\mathrm{C}$ stocks and the measured or calculated variables (the TWI, tree density, $\mathrm{C}_{130}, \mathrm{C} / \mathrm{N}$ in the upper $5 \mathrm{~cm}$ of the soil, organic horizon thickness, slope and percentage cover of understorey vegetation) were not strictly linear. In order to predict $\mathrm{C}$ stocks in waterlogged zones, tree regressions were preferred to the multiple regression method. The data was analysed using the TANAGRA software [34]. 
Table I. Statistics of the C stocks in the different ecosystem components for the two study sites.

\begin{tabular}{|c|c|c|c|c|c|c|}
\hline \multirow[b]{3}{*}{ Ecosystem component } & \multicolumn{6}{|c|}{$\mathrm{C}$ stocks $\left(\mathrm{kg} \mathrm{m}^{-2}\right)$} \\
\hline & \multicolumn{3}{|c|}{ GEN } & \multicolumn{3}{|c|}{ STE } \\
\hline & 1st Quartile & Median & 3rd Quartile & 1st Quartile & Median & 3rd Quartile \\
\hline Trees & 7.6 & 17 & 32 & 9.44 & 13.4 & 16.2 \\
\hline Humus & 1.5 & 2.3 & 2.9 & 0.9 & 1.2 & 1.7 \\
\hline Soil $(0-90 \mathrm{~cm})$ & 13.4 & 15.5 & 19 & 13.5 & 15.2 & 17.1 \\
\hline Total & 28.2 & 35.7 & 47.7 & 26.6 & 30.3 & 33.7 \\
\hline
\end{tabular}

Table II. Statistics of dry matter, carbon content and stock depending on humus type according to Jabiol et al. 1995. Different letters in a column indicate a significant difference using the Wilcoxon-Mann-Whitney test at the 5\% threshold.

\begin{tabular}{lccccccccc}
\hline & \multicolumn{3}{c}{ Dry matter $\left(\mathrm{kg} \mathrm{m}^{-2}\right)$} & \multicolumn{3}{c}{ Carbon content $(\%)$} & \multicolumn{3}{c}{ Carbon stock $\left(\mathrm{kg} \mathrm{m}^{-2}\right)$} \\
\cline { 2 - 9 } Humus type & 1st Quartile & Median & 3rd Quartile & 1st Quartile & Median & 3rd Quartile & 1st Quartile & Median & 3rd Quartile \\
\hline Oligomull & 1.5 & $2.3^{\mathrm{a}}$ & 3 & 41.2 & $45 \mathrm{a}$ & 47.5 & 0.7 & $0.9^{\mathrm{a}}$ & 1.3 \\
Dysmull & 2.9 & $3.5^{\mathrm{b}}$ & 4.4 & 46.1 & $47.7^{\mathrm{a} . b}$ & 48.6 & 1.4 & $1.6^{\mathrm{b}}$ & 2.1 \\
Eumoder & 3 & $3.7^{\mathrm{b}}$ & 4.7 & 42.3 & $46.6^{\mathrm{a} . \mathrm{b}}$ & 49 & 1.4 & $1.7^{\mathrm{b}}$ & 2.2 \\
Dysmoder & 5 & $6^{\mathrm{c}}$ & 6.9 & 45.2 & $47.4^{\mathrm{b}}$ & 49.3 & 2.3 & $2.7^{\mathrm{c}}$ & 3.2 \\
\hline
\end{tabular}

Table III. Statistics of $\mathrm{C}_{130}$ and $\mathrm{C}$ stocks in individual trees.

\begin{tabular}{lcccccc}
\hline & \multicolumn{3}{c}{ GEN } & & STE \\
\hline & 1st Quartile & Median & 3rd Quartile & 1st Quartile & Median & 3rd Quartile \\
\hline $\mathrm{C}_{130}(\mathrm{~cm})$ & 23.7 & 77.4 & 137 & 17.5 & 28.4 & 68 \\
$\mathrm{C}_{130}$ of beech trees $(\mathrm{cm})$ & 18.3 & 59.3 & 105.9 & 18.1 & 27.7 & 62 \\
$\mathrm{C}_{130}$ of oak trees $(\mathrm{cm})$ & 146 & 175.5 & 208.1 & 64.9 & 79.0 & 94.1 \\
$\mathrm{C}$ Stock by individual tree $(\mathrm{kg})$ & 11 & 210 & 863 & 6 & 18 & 147 \\
\hline
\end{tabular}

\section{RESULTS}

\subsection{Carbon stocks at both sites and in the different pools}

The median total $\mathrm{C}$ stock in the GEN plot was $5.4 \mathrm{~kg} \mathrm{C} \mathrm{m}^{-2}$ higher than in the STE plot (Tab. I). The contribution of each carbon pool to the total stock also differed. In the GEN site, trees accounted for more than $50 \%$ of the sequestered carbon, and soil represented $42 \%$. Conversely, the major part of the carbon in the STE site was stored in soils (52\%) and only 44\% in trees. Litter and understorey vegetation represented smaller proportions of the total stock and were about $5 \%$ and $0.1 \%$ respectively. Using the relative importance of each compartment, it was the variability of the soil and tree compartments which most affected the total carbon stocks.

Median SOC stocks did not differ significantly between the GEN and STE plots (Wilcoxon-Mann-Whitney test, $p<$ $0.05)$. Nevertheless, the soil was a pool with spatial variations of carbon stocks ranging from 5 to $43 \mathrm{~kg} \mathrm{C} \mathrm{m}^{-2}$ and SOC stocks presented a higher variability in the GEN plot than in the STE plot (Tab. I). Four types of carbon profiles were distinguished: (A) a profile showing an exponential decrease in carbon content with depth; (B) a second profile also with an exponential content decrease but with $\mathrm{C}$ contents higher than $2 \%$ at $30 \mathrm{~cm}$; (C) a profile with homogeneous carbon contents down to $40 \mathrm{~cm}$ and (D) a profile showing a buried organic horizon deeper than $40 \mathrm{~cm}$, observed near the stream of the STE site. Types A, B, C and D accounted respectively for 60, 24, 8 and $8 \%$ of the profiles in the STE site and 50, 38, 12 and $0 \%$ in the GEN site [13].

Humus carbon stocks were also highly variable with values ranging from $0.1 \mathrm{~kg} \mathrm{~m}^{-2}$ in the GEN site to $6.8 \mathrm{~kg} \mathrm{~m}^{-2}$ in the STE site (Tab. II). Median carbon stocks differed with the humus type considered (Kruskall-Wallis test: $p<0.05$ ) (Tab. II). Oligomulls had the lowest median carbon stock value of $0.9 \mathrm{~kg} \mathrm{~m}^{-2}$ and dysmoders had the highest median carbon stock value of $2.7 \mathrm{~kg} \mathrm{~m}^{2}$. Stocks in dysmulls and eumoders were similar. The $\mathrm{C}$ stock variability between humus samples was mainly explained by the biomass variations (Pearson correlation index $R=0.98, n=200$ ).

Despite a lower tree density, the carbon stock in trees was higher in the GEN plot (Tab. I). This was explained by higher stocks in individual trees: the median stock was estimated to be $210 \mathrm{~kg} \mathrm{C}$ per tree in the GEN site compared with $18 \mathrm{~kg} \mathrm{C}$ per tree in the STE site (Tab. III). It should be noted that oak trees, which represented $18 \%$ of the GEN plot and $10 \%$ of the STE plot, accounted for $42 \%$ of total carbon stock in trees.

\subsection{Spatial structure of carbon stocks}

At both sites, carbon stocks show large differences in the different ecosystem components at short distances and along the slopes (Fig. 2). Variograms estimated on both sites showed 

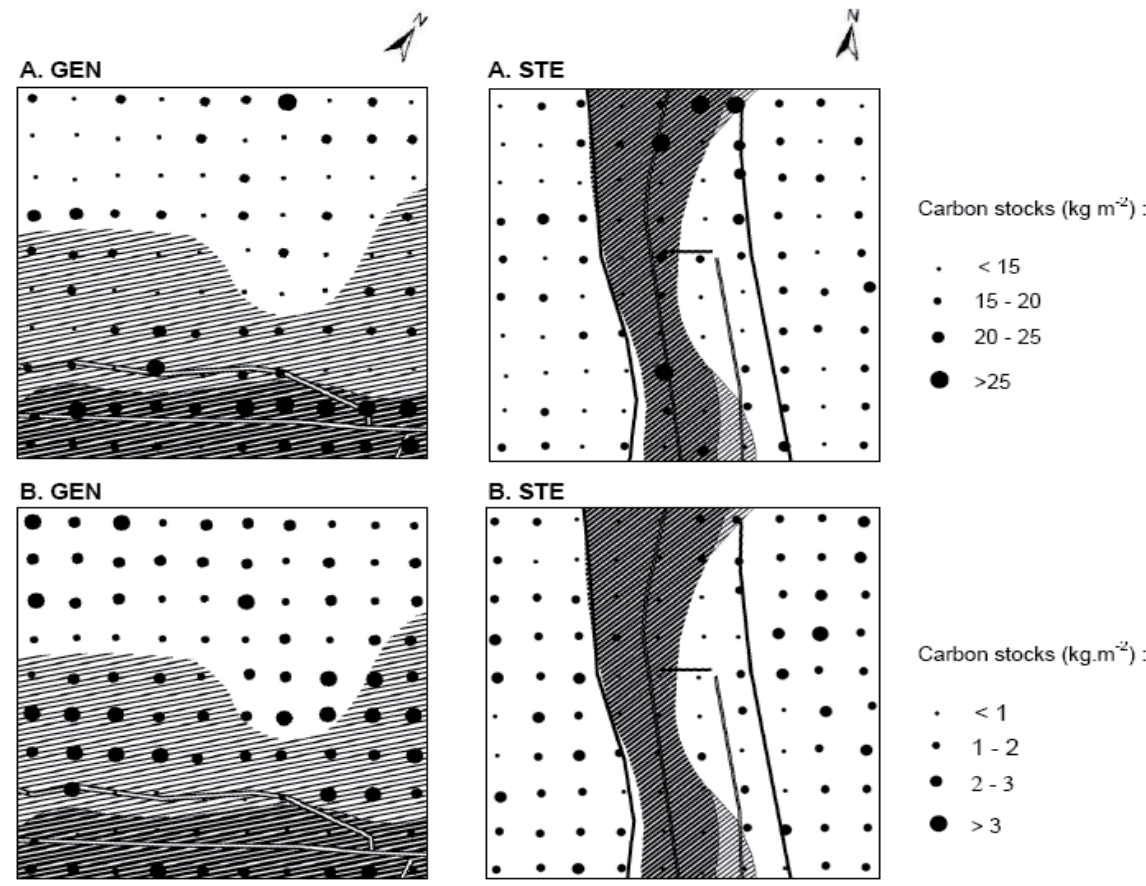

Carbon stocks $\left(\mathrm{kg} \cdot \mathrm{m}^{-2}\right)$

\section{GEN}

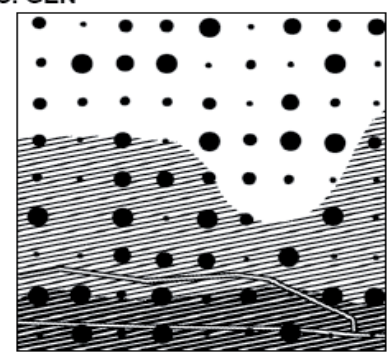

C. STE

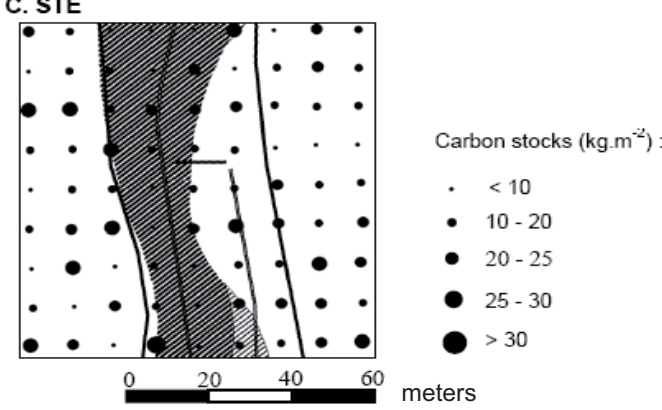

Classes of soil redoximorphism:

. $<1$

- $1-2$

- $2-3$

- $>3$

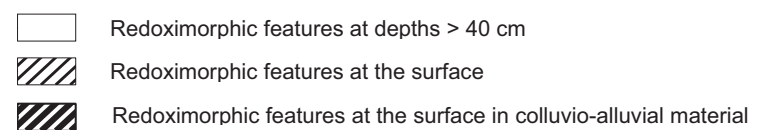

Figure 2. Representation of measured carbon stocks in soil down to $90 \mathrm{~cm}$ (A), in humus (B) and in vegetation (trees and understorey vegetation) (C) related to the soil redoximorphism map on the two sites, GEN and STE. Embankments are represented by bold lines and streams by double lines.

a similar ranking of the components regarding spatial variability at all distances: semi-variance always increased when considering understorey vegetation, humus, soil and trees respectively (Fig. 3).

Increasing variograms with distance were observed for soil carbon down to $90 \mathrm{~cm}$ and humus carbon stocks on both sites (Fig. 3). A similar structure was observed for understorey vegetation at the STE site alone. For the SOC stocks, variogram range (the distance beyond which data points were not correlated) was longer for the GEN site (more than $60 \mathrm{~m}$ ) than for the STE site $(20 \mathrm{~m})$. At the bottom of the valley of the STE site, punctual (at specific sampling points) SOC stocks were highly variable at distances of $10 \mathrm{~m}$ (Fig. 2).

Carbon stocks in trees had a complex distribution with large variations and no spatial structure. On the GEN site, variability was very high in the valley (from 2.4 to $35.5 \mathrm{~kg} \mathrm{C} \mathrm{m}^{-2}$ ). C stocks on the slopes were less variable with values ranging from 9.32 to $29.80 \mathrm{~kg} \mathrm{C} \mathrm{m}^{-2}$.

Embankments in STE site were characterized by an accumulation of carbon in the soil and thicker organic horizons, but low carbon stocks in the vegetation and litter (Fig. 2).

\subsection{Carbons stocks and soil hydromorphy}

Redoximorphic soils stored more carbon than well-drained soils in the GEN site but not in the STE site (Fig. 2 and Tab. IV). However, variability of carbon stocks in this class of soils was of the same order in both sites. Redoximorphism and type of soil profile were not independent $\left(\chi^{2}=53.7 p<\right.$ 0.0001 ). Eighty-two percent of soils with high carbon contents at depths superior to $30 \mathrm{~cm}$ (the C-type profile described previously) were described as soils with redoximorphic features 
$\mathbf{A}$

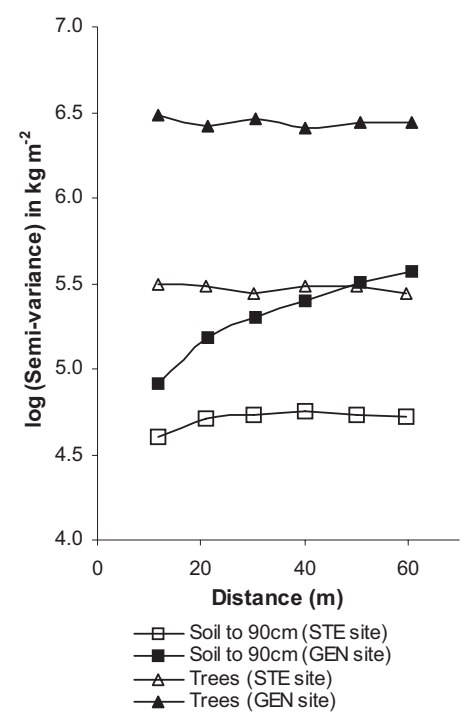

B

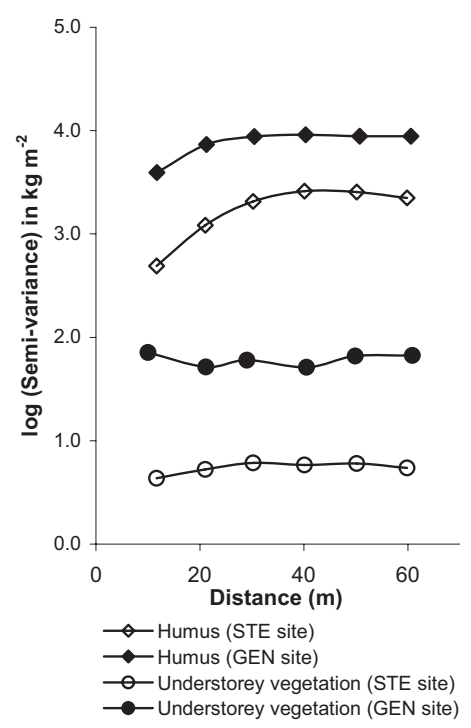

Figure 3. Mean variograms of carbon stocks in soil down to $90 \mathrm{~cm}$ and trees (A), and in humus and understorey vegetation (B) for the two sites GEN and STE.

close to the surface. C-type profiles were also described on top of the embankments. $75 \%$ of well-drained soils showed a rapid exponential decrease in carbon content with depth (Atype profile). Soils with eluvial horizons had low carbon stock values with a median stock of $9.83 \mathrm{~kg} \mathrm{~m}^{-2}$. Therefore, carbon stocks in redoximorphic soils presented a higher variability than in well-drained soils (Tab. IV).

Humus on waterlogged soils sequestered less carbon than humus on well-drained soils in the STE site but not in the GEN site. Soil redoximorphism and humus type were also not independent $\left(\chi^{2}=34.6, p<0.0001\right)$. Oligomulls with low stock values predominated in redoximorphic zones. Nevertheless, these zones were also characterized by low tree density values $\left(1.5\right.$ trees per $\left.100 \mathrm{~m}^{2}\right)$.

\subsection{Carbon stocks prediction using waterlogging intensity modelling}

Estimated topographic wetness index (TWI) was correlated to SOC stocks on both sites (Fig. 4). We determined a TWI value allowing the discrimination of SOC stocks on both sites. We found that an index superior to a threshold of $11.5 \log \left(\mathrm{m}^{2} \mathrm{~m}^{-1}\right)$ indicated soils with a significantly higher median carbon stock than soils with a lower index. Nevertheless, soils with a high TWI value presented the same large variability of carbon stocks as the redoximorphic soils (Fig. 4).

Conversely to SOC stocks, no common TWI value was found to discriminate $\mathrm{C}$ stocks in the vegetation on either site. On the GEN site, median carbon stocks increased with TWI. However, this increase was not statistically significant. On the STE site, index values superior to $11.5 \log \left(\mathrm{m}^{2} \mathrm{~m}^{-1}\right)$ were linked to low median carbon stocks in vegetation and low variability in comparison to classes with lower TWI.
The tree regression models developed, were not very accurate for the prediction of $\mathrm{C}$ stocks in soils and vegetation. Pearson correlations between predicted and measured values were inferior or equal to 0.5 (Tab. V). However, they were generally more predictive than equivalent standard multiple regressions, confirming that relationships between the variables were not strictly linear (data not shown).

For SOC stocks, the best predictive variables were the TWI indices on both sites, the thickness of the organic horizon on the GEN site and the $\mathrm{C} / \mathrm{N}$ ratio in the upper $5 \mathrm{~cm}$ of the soil in the STE site. These variables were positively correlated to SOC stocks. After pooling the data from both sites, only the TWI index allowed the discrimination of SOC stocks in the soils.

For $\mathrm{C}$ stocks in the vegetation, the significant predictive variables were the average $C_{130}$ and the number of trees in the grid meshes. After pooling the data from both sites, the average $\mathrm{C}_{130}$ was the only significant predictive variable.

SOC stocks were predicted better than $C$ stocks in the vegetation. For each site and for the whole dataset, $R^{2}$ were higher and the RMSEs were lower for the model of SOC stocks compared to the model of $\mathrm{C}$ stocks in the vegetation (Tab. V).

\section{DISCUSSION}

\subsection{Carbon stocks in the ecosystem components}

Median total stocks in the STE and GEN sites were lower than stocks at the forest-scale; respectively 6 and $2 \mathrm{~kg} \mathrm{C} \mathrm{m}^{-2}$ lower than values estimated in similar stands [25]. This could be the consequence of the inferior stocks in trees of 7 and $5 \mathrm{~kg} \mathrm{C} \mathrm{m}^{-2}$ respectively.

With median values of 15.2 and $15.5 \mathrm{~kg} \mathrm{C} \mathrm{m}^{-2}$, the SOC stocks estimated in our study were comparable to soil carbon 
Table IV. Statistics of C stocks for two soil redoximorphism levels. The index letter within a column for the same site indicates significant difference using the Wilcoxon-Mann-Whitney test at the 5\% threshold.

\begin{tabular}{|c|c|c|c|c|c|c|c|c|c|}
\hline \multirow[b]{3}{*}{ Soil redoximorphism } & \multicolumn{9}{|c|}{ C Stocks $\left(\mathrm{kg} \mathrm{m}^{-2}\right)$} \\
\hline & \multicolumn{3}{|c|}{ Soil $(0-90 \mathrm{~cm})$} & \multicolumn{3}{|c|}{ Humus } & \multicolumn{3}{|c|}{ Vegetation } \\
\hline & 1st Quartile & Median & 3rd Quartile & 1st Quartile & Median & 3rd Quartile & 1st Quartile & Median & 3rd Quartile \\
\hline GEN No redoximorphic features & 13.4 & $14.9^{\mathrm{a}}$ & 16.8 & 2 & $2.3^{\mathrm{a}}$ & 2.9 & 10.2 & $16.3^{\mathrm{a}}$ & 22.7 \\
\hline Redoximorphic features & 13.5 & $17.1^{\mathrm{b}}$ & 20.4 & 1.4 & $2.2^{\mathrm{a}}$ & 2.8 & 3.3 & $17.1^{\mathrm{a}}$ & 39.5 \\
\hline $\begin{array}{ll}\text { STE } & \text { No redoximorphic features }\end{array}$ & 13.6 & $15.2^{\mathrm{a}}$ & 16.5 & 1 & $1.4^{\mathrm{a}}$ & 1.9 & 9.9 & $13.4^{\mathrm{a}}$ & 16.3 \\
\hline Redoximorphic features & 12.8 & $15.2^{\mathrm{a}}$ & 20 & 0.4 & $0.7^{\mathrm{b}}$ & 1 & 6.9 & $11.8^{\mathrm{b}}$ & 15.6 \\
\hline
\end{tabular}
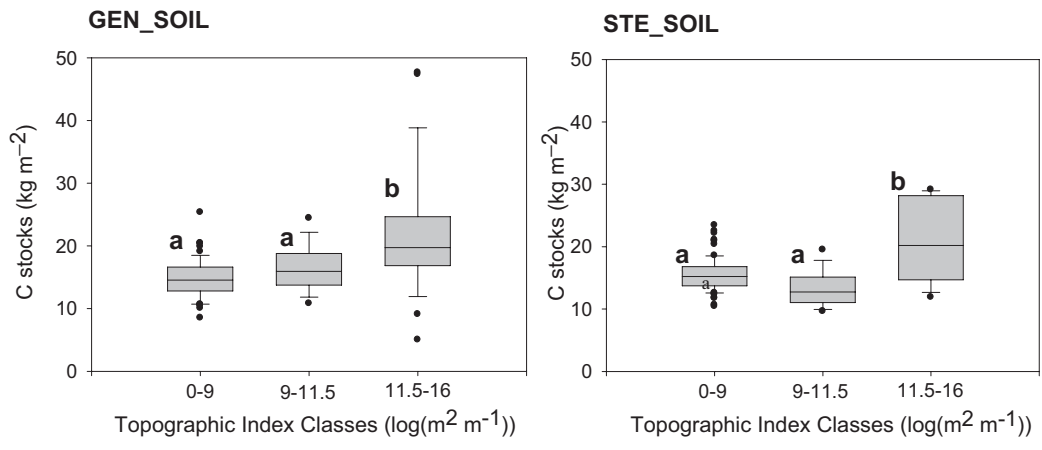

GEN_VEG
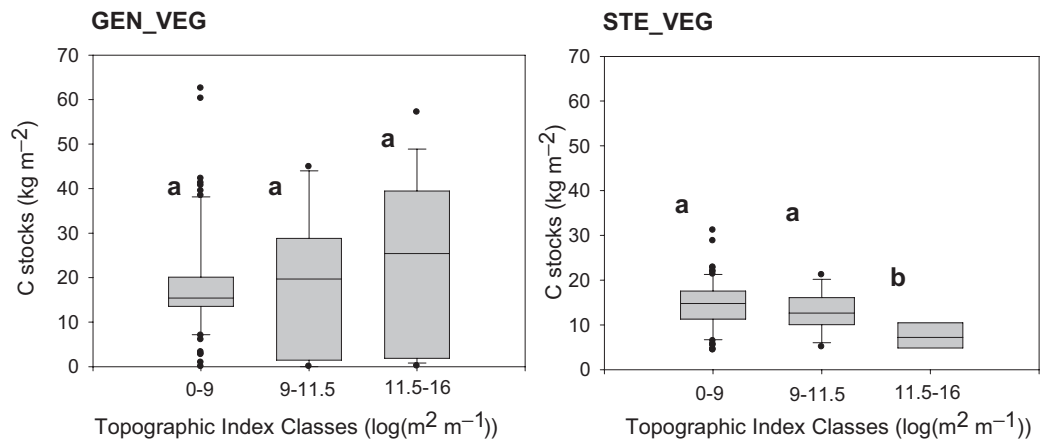

Figure 4. Statistics (median, quartiles, range) of carbon stocks in soil down to $90 \mathrm{~cm}$ and in vegetation estimated for three classes of topographic wetness index in the GEN and STE sites. C stocks in vegetation were estimated from the total stock in each $100 \mathrm{~m}^{2}$ elementary cells of the sampling grid. The index letter within a plot indicates significant difference using Wilcoxon-Mann-Whitney test at the 5\% threshold.

stocks estimated in other temperate forests. For example, the average stock in the first metre of Belgian soils was estimated to be $14.4 \mathrm{~kg} \mathrm{C} \mathrm{m}^{-2}$ [27]. Stocks in understorey vegetation were similar to those estimated in two plantations in Fougères forest: an 83-year-old stand and a 144-year-old stand which sequestered about 0.33 and $0.88 \mathrm{~kg} \mathrm{C} \mathrm{m}^{-2}$ respectively [16].

Total carbon stock variability on both sites was lower than the variability estimated in redoximorphic zones by [25]. This could be explained by the predominance of well-drained soils at the slope-scale. Moreover, the "redoximorphic zones" defined by the authors of this paper included a wide variety of plantations (age and species) and environments (topography).

\subsection{Impact of waterlogging on carbon stocks}

Most redoximorphic soils were characterized by high carbon contents at a depths superior to $30 \mathrm{~cm}$ or by eluvial hori- zons with low carbon contents. High carbon contents in deep horizons were linked to an accumulation of carbon or buried organic material. Soils with an accumulation of carbon generally presented thick organic horizons. Burying was probably caused by the deposit of alluvium and colluvium which cover and thus protect organic material from rapid degradation. In both sites, the gradient between the lowest SOC stock at the top of the slopes and the highest SOC stock at bottom of the valley may be related to waterlogging and the intensity of carbon accumulation (Fig. 2). The topography explains the progressive or the fast transition in the GEN and STE sites respectively. However, processes of carbon redistribution may also occur at the bottom of the valley in the STE site due to silt deposits and erosion by stream flow. According to the literature, runoff and erosion in forests are generally lower than in denuded and arable areas, and are similar to or greater than in pasture and shrub-land $[9,15,40]$. These processes are related to rainfall characteristics (volume, intensity, duration and 
Table V. Results of the data analysis on the C stocks in soil and vegetation by tree regression method. Mean C130 and N. trees are the mean $\mathrm{C}_{130}$ of the trees and the number present in the $100 \mathrm{~m}^{2}$ grid mesh respectively, $\mathrm{OH}$ is the thickness of the organic horizon. The TWI index is expressed in $\log \left(\mathrm{m}^{-2} \mathrm{~m}^{-1}\right)$.

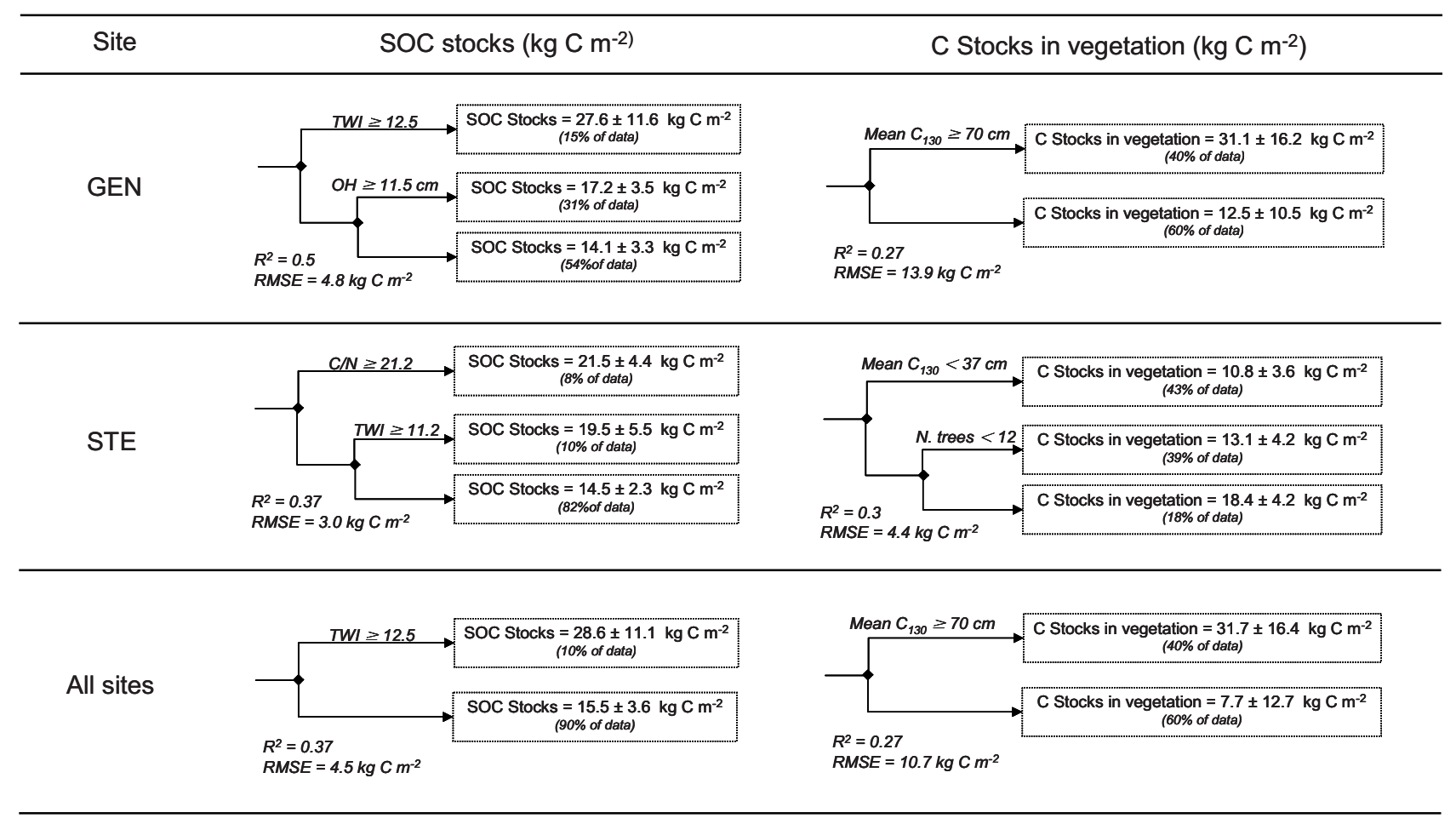

frequency), soil parameters, topography and vegetation structure. In particular, vegetation cover reduces the quantity of water that reaches the soil due to an interception effect [4]. Chirino et al. 2006 [9] observed an increase in soil losses and runoff with a diminution of vegetation cover. The STE site presented low understorey vegetation cover (33\%), low tree density at the bottom of the valley $\left(1.5\right.$ trees per $\left.100 \mathrm{~m}^{2}\right)$ and a mean slope of $25 \%$. Thus, runoff and erosion processes could explain the presence of alluvial horizons and the wide variability of SOC stocks occurring within short distances, which were observed at this site (Fig. 2).

The major impacts of soil waterlogging on vegetation were a decrease in tree density and an increase in species diversity. Beeches grow better on well-drained soils and under shade whereas pedunculate oaks are favoured by deep wet soils and low tree densities [28]. In this study, hydromorphic zones are characterized by the predominance of oaks and a high spatial variability of carbon stocks in vegetation due to individual oaks which constitute the highest stock for some trees (up to $3000 \mathrm{~kg} \mathrm{C}$ ). However, median carbon stocks did not differ statistically between well-drained and waterlogged zones (Tab. IV).

Stocks in wetlands were lower in humus horizons and higher in the understorey vegetation. This may be related to the impact of soil hydromorphy on tree density and species composition. In waterlogged zones, tree density was lower, litterfall was small and understorey vegetation received more radiance.

\subsection{Other determinants of carbon distribution}

Difference between the stock values of the two sites can be mainly explained by the age and tree density of the forest stands. Indeed, a 120-year-old stand generally represents a higher stock of carbon than a 60-90 year-old-stand [16, 24]. In old stands, trees are bigger, litter and dead woody material have accumulated for longer and the lower tree density favours understorey vegetation growth. Moreover, variability of humus form in beech stands has been shown to be related to the spatial pattern of stand canopy and its species composition [2].

On the STE site, the embankments and the ditch had an impact on the spatial distribution of carbon in the different components of the ecosystem. Firstly, they directed water flow and modified the spatial distribution of redoximorphic soils. Secondly, embankments were also sites of organic matter deposit caused by upslope soil erosion and the steep slope limited the growth of vegetation.

\subsection{Significance of waterlogging intensity models in the prediction of carbon stocks}

SOC stocks differed significantly depending on the estimated TWI on both sites. However, this relation was different at the two sites and was significant in the STE site only. On the GEN site, no significant differences in stock were observed although classes of TWI superior to $11.5 \log \left(\mathrm{m}^{2} \mathrm{~m}^{-1}\right)$ 
were associated with the higher median stock $\left(26.2 \mathrm{~kg} \mathrm{C} \mathrm{m}^{-2}\right)$. On the STE site, this class was characterized by low $\mathrm{C}$ stock compared to the whole site. The tree regression models confirmed the significance of the TWI index in predicting SOC stocks in both sites. Variables characterizing the turn over rate of the soil organic matter (the thickness of the organic horizon and the $\mathrm{C} / \mathrm{N}$ of the upper $5 \mathrm{~cm}$ of soil) also improved the predictive power of the model. For $\mathrm{C}$ stocks in vegetation, it was the characteristics of the stand in terms of tree density and mean $\mathrm{C}_{130}$ which were the most significant. When data from both sites were pooled, there was an important site effect. The mean $\mathrm{C}_{130}$ discriminated the two sites, which differed significantly in terms of $\mathrm{C}$ stocks in trees (Tab. I) and median $\mathrm{C}_{130}$ (Tab. III).

The TWI index improved SOC stock predictions in the redoximorphic zone but was inadequate for estimating $\mathrm{C}$ stocks in the vegetation.

\section{CONCLUSION}

In this study, we estimated carbon stocks in the vegetation, soils and humus and their spatial variability at the slope scale. The two sites studied made it possible to analyze the influence of waterlogging intensity on these stocks. Results have shown that SOC stocks were significantly higher and had a range of variation 2 to 3 times higher in the redoximorphic zone than stocks in the well-drained zone. Spatial variability in soil carbon stocks was correlated to waterlogging intensity and topography. Modelling of waterlogging intensity by a topographic wetness index improved SOC stock estimates in redoximorphic zones. However, the model developed in this study had low accuracy with a $R^{2}$ of 0.37 and an RMSE of $4.5 \mathrm{~kg} \mathrm{C} \mathrm{m}^{-2}$. This lack of precision could be linked to the roles of the forest management and the past land use on the soil distribution. The embankments in the STE site were evidence of the presence of agricultural activity in the past.

Conversely, it was the age and density of the stand which had most influence on the variability of carbon stocks in the vegetation. Forest management appears therefore to be the main explanatory factor. Stocks in hydromorphic zones were weaker in the humus and higher in the understorey vegetation, and were related to the impact of the hydromorphy on the trees in terms of density and species composition. Therefore, the variability of stocks in hydromorphic zones evaluated within these compartments cannot be simply linked to topography and waterlogging intensity.

Acknowledgements: Many thanks to all the people who assisted with the field and laboratory work, without whom this project would not have been possible: G. Dutin, J.C Marie, B. Lemercier, S. Didier, L. Gelhaye, C. Antoine, J. Marchand. The authors are grateful to the Office National des Forêts for facilitating experimental work in the Fougères forest. This work was financed by the GIP-ECOFOR and the Office National des Forêts as one of the Environmental Research sites on "Lowland beech". The English was corrected by Aldyth Nys.

\section{REFERENCES}

[1] AFES, Le référentiel pédologique. Principaux sols d'Europe, $2^{\mathrm{e}}$ éd., INRA éd., 1995.

[2] Aubert M., Margerie P., Ernoult A., Decaens T., Bureau F., Variability and heterogeneity of humus form at stand level: Comparison between pure beech and mixed beech-hornbeam forest, Ann. Sci. For. 63 (2006) 177-188.

[3] Belkacem S., Nys C., Dupouey J.L., Évaluation des stocks de carbone dans les sols forestiers : importance de la sylviculture et du milieu sur la variabilité, INRA Nancy, 1998.

[4] Bellot J., Escarré A., Stemflow and throughfalll determination in a resprouted Mediterranean holm-oak forest, and changes by precipitation trends, Ann. Sci. For. 52 (1998) 847-865.

[5] Beven J.K., Kirkby M.J., A physically based variable contributive area model of basin hydrology, Hydrol. Sci. Bull. 24 (1979) 43-69.

[6] Brown S., Schroeder P.E., Spatial patterns of aboveground production and mortality of woody biomass for eastern US forests, Ecol. Appl. 9 (1999) 968-980.

[7] Chaplot V., Organisation spatiale des sols hydromorphes de fonds de vallée. Modélisation prédictive de leur distribution, ENSA Rennes, 1998.

[8] Chaplot V., Walter C., Improving the spatial prediction of soils at local and regional levels through a better understanding of soillandscape relationships: soil hydromorphy in the Armorican Massif of western France, in: Lagacherie P., McBratney A., Voltz M. (Eds), Digital soil mapping. An introductory perspective, Developments in Soil Science, Elsevier, vol. 31, 523-538.

[9] Chirino E., Bonet A., Bellot J., Sanchez J.R., Effects of 30-year-old Aleppo pine plantations on runoff, soil erosion and plant diversity in a semi-arid landscape in south eastern Spain, Catena 65 (2006) $19-29$.

[10] Curmi P., Bourrie G., Merot P., Widiatmaka, Maître V., Analyse structurale d'un versant granitique (massif de Quintin, Bretagne). Implications sur le fonctionnement hydrique et géochimique, Bull. Assoc. Géogr. Fr. 2 (1998) 88-89.

[11] Davidson, E.A., Verchot L.V., Cattânio J.H., Ackerman I.L., Carvalho J.E.M., Effects of soil water content on soil respiration in forests and cattle pastures of eastern Amazonia, Biogeochemistry 48 (2000) 53-69.

[12] Dixon R.K., Brown S., Houghton R.A., Solomon A.M., Trexler M.C., Wisniewski J., Carbon pools and flux of global forest ecosystems, Science 263 (1994) 185-190.

[13] Eglin T., Impact de l'hydromorphie et de la topographie sur la variabilité spatiale des stocks de carbone en forêt de Fougères (Ille-etVillaine) : étude à l'échelle de versants, Master Publication, 2003.

[14] Howard D.M., Howard P.J.A., Relationships between $\mathrm{CO}_{2}$ evolution, moisture content and temperature for a range of soil types, Soil Biol. Biochem. 25 (1993) 1537-1546.

[15] Huang Z.L, Chen L.D., Fu B.J., Lu Y.H., Huang Y.L., Gong J., The relative efficiency of four representative cropland conversions in reducing water erosion: evidence from long-term plots in the Loess hilly area, China, Land and Degradation Development, 17 (2006) 615-627.

[16] Huet S., Contribution à l'étude du fonctionnement carboné d'une hêtraie de plaine atlantique, incluant sa végétation de sous-bois, dans une chrono-séquence, Thèse d'université, mention Biologie, Rennes 1, 2001.

[17] Hyvönen R., Ågren G.I., Linder S., Persson T., Cotrufo M., Ekblad A., Michael F., Grelle A., Janssens I.A., Jarvis P.G., Kellomäki S., Lindroth A., Loustau D., Lundmark T., Norby R.J., Oren R., Pilegaard K., Ryan M.G., Sigurdsson B.D., Strömgren M., van Oijen M., Wallin G., The likely impact of elevated $\left[\mathrm{CO}_{2}\right]$, nitrogen deposition, increased temperature and management on carbon sequestration in temperate and boreal forest ecosystems: a literature review, New Phytol. 173 (2007) 463-480. 
[18] IPCC, Special report on land use, land-use change and forestry, 1998.

[19] Ishizuka S., Sakata T., Sawata S., Ikeda S., Takenaka C., Tamai N., Sakai H., Shimizu T., Kan-na K., Onodera S., Tanaka N., Takahashi $\mathrm{M}$., High potential for increase in $\mathrm{CO}_{2}$ flux from forest soil surface due to global warming in cooler areas of Japan, Ann. For. Sci. 63 (2006) 537-546

[20] Jabiol B., Brêthes A., Ponge J.F., Toutain F., Brun J.J., L'humus sous toutes ses formes, ENGREF, 1995.

[21] Ju W., Chen J.M., Distribution of soil carbon stocks in Canada's forests and wetlands simulated based on drainage class, topography and remotely sensed vegetation parameters, Hydrol. Process. 19 (2005) 77-94.

[22] Kauppi P.E., New, low estimate for carbon stock in global forest vegetation based on inventory data, Silva Fenn. 37 (2003) 451-457.

[23] Krogh L., Nóergaard A., Hermansen M., Greve M.H., Balstroem T., Breuning-Madsen H., Preliminary estimates of contemporary soil organic carbon stocks in Denmark using multiple datasets and fourscaling-up method, Agric. Ecosyst. Environ. 96 (2003) 19-28.

[24] Lebret M., Les humus forestiers en hêtraies de plaine : analyse des facteurs de l'évolution sur une chrono-séquence, Ph.D. thesis, University of Rennes, 2002, $350 \mathrm{p}$.

[25] Lecointe S., Nys C., Walter C., Forgeard F., Huet S., Recena P., Follain S., Estimation of carbon stocks in the Fougères forest (W. France): from the plot to the whole forest, Ann. For. Sci. 63 (2006) $139-148$.

[26] Legout A., Étude des stocks en éléments nutritifs des sols de la forêt de Fougères à différentes échelles d'espace, Master publication, 2004.

[27] Lettens S., Orshoven J.V., Van Wesemael B., De Vos B., Muys B., Stocks and fluxes of soil organic carbon for landscape units in Belgium derived from heterogeneous data sets for 1990 and 2000 Geoderma 127 (2004) 11-23.

[28] Lieutaghi P., Le livre des Arbres, Arbustes et Arbrisseaux, Actes Sud, 2004.

[29] Liski J., Perruchoud D., Karjalainen T., Increasing carbon stocks in forest soils of Western Europe, For. Ecol. Manage. 169 (2002) 159-175.

[30] Nabuurs, G.J., R. Päivinen, R. Sikkema, G.M. Mohren. The role of European forests in the global carbon cycle: a review, Biomass Bioenergy 13 (1997) 345-358.

[31] Nys C., Le site-atelier de Fougères (Ille-et-Vilaine) : Hêtre de plaine, ORE fonctionnement des écosystèmes, 2003.
[32] Ostendorf B., Reynolds J.F., A model of arctic tundra vegetation derived from topographic gradients, Landsc. Ecol. 13 (1998) 187201.

[33] Piégay H., Pautou G., Ruffinoni C., Les forêts riveraines des cours d'eau : écologie, fonctions, gestion, Institut pour le Développement Forestier, Paris, 2003.

[34] Rakotomalala R., TANAGRA : un logiciel gratuit pour l'enseignement et la recherche, in: Actes de EGC'2005, RNTI-E-3 vol. 2, pp. 697-702.

[35] Schulze, E.D., Lloyd J., Kelliher F.M., Wirth C., Rebmann C., Lühker B., Mund M., Knohl A., Milyukova I.M., Schulze W., Ziegler W., Varlagin A.B., Sogachev A.F., Valentini R., Dore S., Grigoriev S., Kolle O., Panfyorov M.I., Tchebakova N., Vygodskaya N.N., Productivity of forests in the Eurosiberian boreal region and their potential to act as a carbon sink: a synthesis, Glob. Change Biol. 5 (1999) 703-722.

[36] Sprent P., Pratique des statistiques non paramétriques, Collection techniques et pratiques, INRA éd., Paris, 1992.

[37] Turpault M.P., Processus d'altération des minéraux des sols : quantification, à différentes échelles, des facteurs physiques, chimiques et minéralogiques. Exemple d'un sol faiblement lessivé à glosses développé sur limon dans un écosystème de hêtraie de plaine (Fougères), Contrat INRA/INSU, Programme PNSE, Rapport scientifique final, 2002.

[38] UNFCCC, National communication from parties included in Annex I to the convention: greenhouse gas inventory data from 1900 to 1998, FCCC/SBI/2000/11, 2000.

[39] United Nations, Framework Convention on Climate Change. Report on the Conference of the Parties on its Third Session, Kyoto, 1-11 December 1997. Addendum. Part two: Action taken by the conference of the parties at its third session http://unfccc.int/kyoto_protocol/items/2830.php. Accessed March 2007.

[40] Vacca A., Loddo S., Ollesh G., Puddu R., Serra G., Tomasi D., Aru A., Measurement of runoff and soil erosion in three areas under different land use in Sardinia (Italy), Catena 40 (2000) 69-92.

[41] Vallet P., Dhôte J.-F., Le Moguédec G., Ravart M., Pignard G., Development of total aboveground volume equations for 7 important forest tree species in France, For. Ecol. Manage. 229 (2006) 98-110.

[42] Webster R., Oliver M.A., Geostatistics for Environnmental Scientists, Wiley, Chichester, 2000, 271 p.

[43] Zinko U., Seibert J., Dynesius M., Nilsson C., Plant species numbers predicted by a topography-based groundwater flow index, Ecosystems 8 (2005) 430-441. 